\title{
Sexual Dimorphism in Prehispanic Populations of the Cochabamba Valleys, Bolivia*
}

\author{
José A. Cocilovo $^{1 \#}$, María L. Fuchs ${ }^{1}$, Tyler G. O’Brien ${ }^{2}$, Héctor H. Varela ${ }^{1}$ \\ ${ }^{1}$ Departamento de Ciencias Naturales, Facultad de Ciencias Exactas, Físico-Química y Naturales, \\ Universidad Nacional de Río Cuarto, Río Cuarto, Argentina \\ ${ }^{2}$ Department of Sociology, Anthropology and Criminology, University of Northern Iowa, \\ Cedar Falls, USA \\ Email: \#jcocilovo@exa.unrc.edu.ar
}

Received November $17^{\text {th }}, 2012$; revised December $21^{\text {st }}, 2012$; accepted January $1^{\text {st }}, 2013$

\begin{abstract}
The expression of sexual dimorphism may vary across time and space, as well as within and between populations depending on genetic and environmental factors that influence growth and development. The objective of the present work is to contribute to the knowledge of factors that determine the physical characteristics of ancient human groups in the eastern valleys of Cochabamba - a key region for cultural development, inter-regional interaction with northern Chile and northwest Argentina, and their noticeable role in the settlement of the south central Andean region. This paper analyzes the differences between males and females crania representing ancient human groups that inhabited the eastern valleys of Cochabamba, Bolivia. Thirty-one craniometric variables are analyzed from a sample of 234 individuals. Differences are evaluated using univariate analysis by ANOVA and multivariate discriminant analysis. The results indicate the existence of higher mean values in males compared to females in most cranial measurements (mean difference 5.3\%). The discriminant analysis also reveals a significant morphological difference exists between sexes. Furthermore, by means of the discriminant function, the reclassification of correct sex was $99 \%$ of cases. This information indicates that members of this population could live in optimal conditions, with adequate resources to ensure growth and development and normal expression of the phenotype of each sex.
\end{abstract}

Keywords: Sexual Dimorphism; Growth and Development; Population Biology; Craniometrics

\section{Introduction}

Sexual dimorphism is the result of the complex action of a series of genetic and environmental factors linked to the growth and development process of individuals. Although this characteristic is already seen in the fetal development, this is much more evident in the puberal stage of the vital cycle, affecting the anatomy, physiology and behavior. In current populations, normal growth tends to conclude with the development of the secondary sexual characteristics around 16 years old in the female and about 18 years old in the males, with the most conspicuous change being the overall difference in size. This difference is produced by differential growth in regards to duration, intensity and velocity. A complete synthesis of this theme, from an evolutionary perspective, can be found in work by Frayer and Wolpoff (1985). Additional work by Guntupalli and Baten (2009) evaluates stature differences between both sexes from historic and socioeconomic points of view.

Sexual differences manifest themselves at various levels in respect to size and form of the tissue and organ. In particular, the acquisition in the male of greater muscular mass also brings about a greater development of the skeletal system. The bone

\footnotetext{
*The research for this work was supported by grants from Consejo Nacional de Investigaciones Científicas y Técnicas (PIP 2405/08), Universidad Nacional de Río Cuarto (C18/328), Agencia Nacional de Promoción Científica y Técnica (PICT 02210/07) of Argentina; Faculty Fellowship, University of Northern Iowa; and Nacional Science Foundation's doctoral dissertation improvement grant (SBR 9903631).

${ }^{\#}$ Corresponding author.
}

structure reflects these differences in conjunction with anatomic traits. Such characteristics are currently employed in the discrimination of sex in skeletal remains (Saunders, 1992).

The magnitude of sexual dimorphism constitutes a topic of great interest because of its association with growth problems produced by disease and malnutrition. In fact, in situations of chronic stress a reduction of sexual dimorphism is expected but at the expense of normal masculine growth. Males are more ecosensitive and experience a much more marked response to prolonged nutritional shortages (Frayer \& Wolpoff, 1985; Stinson, 1985). Three dramatic examples of the effects on sexual dimorphism by way of nutritional shortages and inefficient sanitary conditions are evident in the cases of Heliconia, Colombia (Stini, 1969), of the Villa IAPI, a poor village outside of Buenos Aires, Argentina (Pucciarelli et al., 1993) and another case in the Republic of Mali, Africa (Dettwyler, 1992). However, in contrast, the Tehuelches and Mapuches, two indigenous groups of Chubut, Argentina, express normal rates of sexual dimorphism in supposedly unfavorable economic and environmental conditions because of the governmental assistance they receive and the social cooperation that permits them to reach an appropriate nutritional state (Pinotti et al., 2005).

This feature was evaluated in current native groups from la Puna in Jujuy in a sample of 231 individuals, by means of 21 somatometric measurements. All the variables showed significant differences between both sexes, and the male mean values were higher than those of the females. This result was very precise as the measurements were performed independently of 
the age effect or any micro-geographical variations (Varela et al., 1990a). Similar results were obtained in native groups from western Chaco (Matacos, Tobas, Chorotes and Chiriguanos) (Priotto, 1990). A more recent work confirmed the results obtained in these ethnic groups (Méndez \& Ferrarini, 2006), in which sexual dimorphism was explained based on the life history of each group, energy intake and utilization of resources.

In current populations, detailed research attests to the anatomical and physiological differences between both sexes. However, in ancient populations any indication of sexual dimorphism or its effects is more often associated with the simple determination of sex from the bones and not the evaluation of such traits as an adaptive process (Giles \& Elliot, 1963; Cocilovo \& Marcellino, 1974; Purkait \& Chandra, 2002, 2004). An earlier analysis of sexual dimorphism is in Keen's (1950) work on the human cranium. In his research, the statistical significance of differences seen between males and females is evaluated statistically by a set of metric variables and discrete traits.

In many studies carried out on skeletal materials from vast regions (Peru, Chile and Argentina), sexual dimorphism expressed across the entire cranium is typically verified to be the main factor of variation (Cocilovo, 1975, 1978; Cocilovo et al., 1982; Cocilovo \& Baffi, 1985; Varela et al., 1990; Cocilovo et al., 1994; Mendonça et al., 1994). Male individuals tend to present systematically greater dimensions than females, while general form of anatomical structures remains constant. For example, statistical tests indicate significant differences exist between sexes in the majority of metric variables, however, indices (or the quotient between two variables), could not always be verified.

In some cases, these facts suggest that major bony development in males, in contrast to women, could be the result of a normal rate of growth, but only in conditions of adequate nutrition and certain lifestyles of the distinct groups. However, a situation in one case finds diametrically opposite results: Las Pirguas (Pampa Grande, Salta, Argentina). Here the differences between males and females are of a smaller magnitude. This information, along with other indicators (low life expectancy at birth, the prevalence of infectious and nutritional pathologies, and social stress indicators), reflects the presence of rigorous environmental circumstances and possibly more intense interaction with other contemporary groups (Baffi \& Cocilovo, 1989; Baffi et al., 1996).

The study of sexual dimorphism is important to assess the biological profile of a population, in respect to its adaptation to specific socio-cultural and environmental conditions. The objective of the present work is to contribute to the knowledge of factors that determine the physical characteristics of ancient human groups in the eastern valleys of Cochabamba-a key region for cultural development, inter-regional interaction with northern Chile and northwest Argentina, and their noticeable role in the settlement of the south central Andean region (Cocilovo et al., 2009).

\section{Materials and Methods}

The series of skulls used for this project come from prehispanic archaeological sites in the eastern valleys of Bolivia around Cochabamba and Sucre. Sites from where skulls were collected temporally range from the Middle Horizon to preconquest $(\sim 0-1450 \mathrm{~s}$ AD) for the South Central Andean region. Figure 1 illustrates the eastern valleys of the Cochabamba

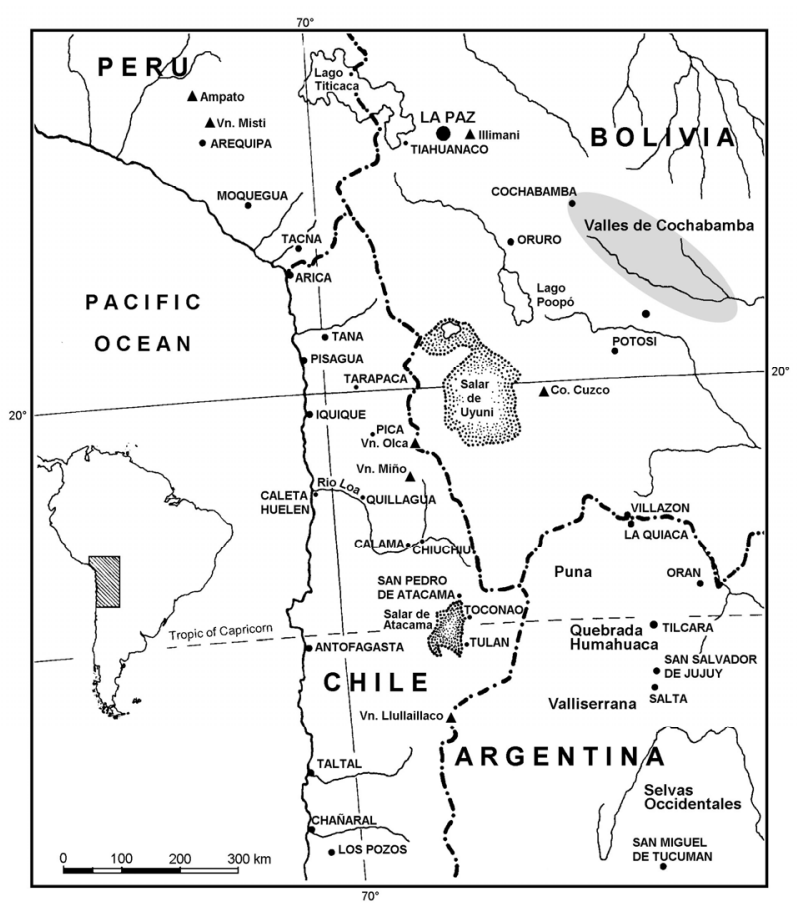

Figure 1.

Location of the Cochabamba samples from the eastern valleys of Bolivia.

region in geographic relation to the capital city of La Paz and Lake Titicaca (O’Brien, 2003).

The observations and measurements were made by one of the authors (TGB) in a set of 234 individuals, that were aged using dental development, attrition patterns (Buikstra \& Ubelaker, 1994; Lovejoy, 1985) and cranial suture obliteration (Masset 1989; Meindl \& Lovejoy, 1985) and were sexed utilizing gross morphological and diagnostic cranial features (Acsadi \& Nemeskeri, 1970; Bass, 1987; Buikstra \& Ubelaker, 1994). Judgment of whether or not a cranium was artificially modified was based on previous work (Dingwall, 1931; Dembo \& Imbelloni, 1938).

Cranial data, derived from 31 metric variables taken across the vault, base and face, are statistically analyzed using a oneway ANOVA analysis to evaluate the differences between male and female skulls (see Figures 2 and 3). Subsequently, the differences between both sexes were evaluated through discriminant analysis (Seber, 1984). Discriminant function analysis verified the correct sex classification on individuals that presented complete data for all variables. For the explanation of the magnitude of the sexual dimorphism, for each variable, an index was calculated as the difference between the mean male (MEDm) and the mean female (MEDf) value in relation to the average female: [(MEDm - MEDf)/MEDf] expressed as a percentage. "Heteromorphic" are those variables which in the ANOVA results showed significant differences between the mean values of one and the other sex, and "isomorphic" those who did not express that difference.

\section{Results}

Table 1 shows the sample distribution according to sex and age; a net predominance of female individuals is observed and 


\section{J. A. COCILOVO ET AL.}

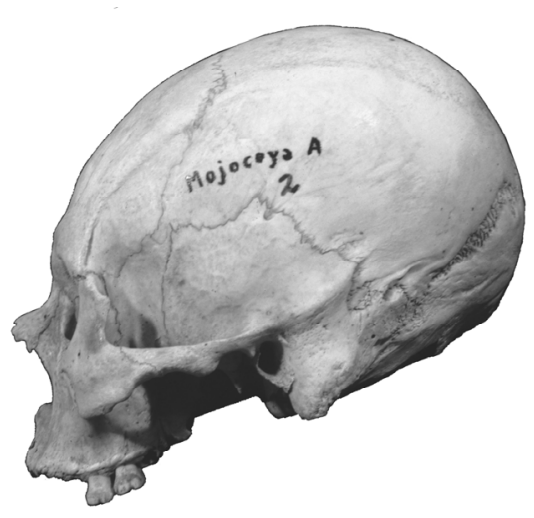

Figure 2.

Example of adult male from the Mojocoya site, Cochabamba.

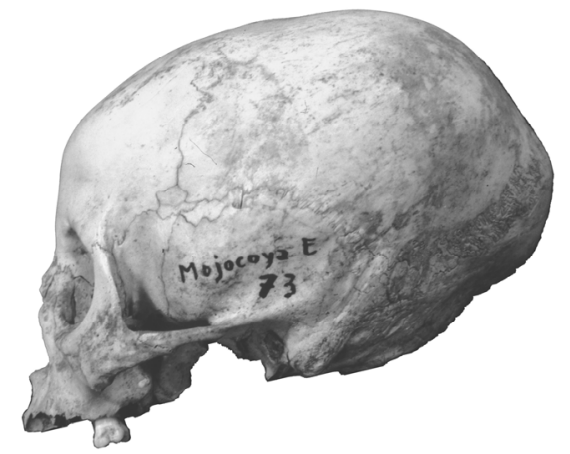

Figure 3.

Example of adult female from the Mojocoya site, Cochabamba.

Table 1.

Distribution of the Cochabamba sample by age and sex.

\begin{tabular}{|c|c|c|c|}
\hline \multirow[b]{2}{*}{ Age } & \multicolumn{2}{|c|}{ Sex } & \multirow{2}{*}{ Total } \\
\hline & Male & Female & \\
\hline Adult & $43(39 \%)$ & $67(61 \%)$ & 110 \\
\hline Mature & $50(52 \%)$ & $46(48 \%)$ & 96 \\
\hline Senile & $7(25 \%)$ & $21(75 \%)$ & 28 \\
\hline Total & 100 & 134 & 234 \\
\hline
\end{tabular}

few senile individuals. Table 2 shows the distribution of both sexes according to artificial cranial deformation. The majority consists of non-deformed individuals (76\%). The other types: tabular erect (TE), tabular oblique (TO) and circular oblique (CO) represent $24 \%$ of all cases. Table 3 displays each variable separated by sex, number of cases $(\mathrm{N})$, mean $(\bar{x})$, standard error (s.e.), and the test for sex differences between means (F).

All but three of the craniometric variables express a significant difference between the sexes $(p<0.01)$. The three exceptions are nasal breadth, orbit height and occipital chord. Overall, males tend to present greater mean values than females (see Figures 4-6). This difference, measured with regard to the female value, is always positive and is distributed with a mean of $4.9 \%$ (s.d. $=0.06 \%$ ) in a range with a low of $2.3 \%$ (for the frontal chord) and a high of $19.4 \%$ (for mastoid length). The magnitude of the difference is smaller in measurements of the
Table 2.

Composition of the Cochabamba sample by sex and artificial deformation type*.

\begin{tabular}{cccccc}
\hline \multirow{2}{*}{ Sex } & \multicolumn{4}{c}{ Artificial Deformation } & \multirow{2}{*}{ Total } \\
\cline { 2 - 5 } & TE & TO & CO & ND & \\
\hline Male & $9(9 \%)$ & $8(8 \%)$ & $5(5 \%)$ & $78(78 \%)$ & 100 \\
Female & $10(7 \%)$ & $9(7 \%)$ & $16(12 \%)$ & $99(74 \%)$ & 134 \\
Total & $19(8 \%)$ & $17(7 \%)$ & $21(9 \%)$ & $176(76 \%)$ & 234 \\
\hline
\end{tabular}

Note: row percentages. ${ }^{*} \mathrm{TE}=$ Tabular erect; $\mathrm{TO}=$ Tabular oblique; $\mathrm{CO}=$ Circular oblique; $\mathrm{ND}=$ no deformation.

vault (mean $=4.4 \%)$ and greater in facial skull measurements $($ mean $=5.4 \%)$.

In general, the adult male tends to possess greater growth and development in the majority of the anatomical substructures of the skull. The greater dimensions are most evident in the vault, neurocranial base, foramen magnum, size of the face and frontal, malar and palatine bones, wider orbits and longer nasal length. Upon considering all the variables together, the results of the discriminant analysis indicate that there is a significant difference between sexes (Wilks' Lambda $=0.21343$, approximate $\mathrm{F}(31$ and $47 \mathrm{df})=5.5876, p<0.0001)$. The reclassification of individuals into the correct sex was $99 \%$ (Table 4). The distributions of male and female agrees with the first canonical discriminant variable accounting for $100 \%$ of the variance (see Figure 7).

\section{Discussion}

The magnitude of sexual dimorphism depends on genetic variation and local conditions such as the availability of food resources to ensure adequate nutrition, in order to guarantee normal growth and development. Such effects are often evident in a metric examination of the skeleton. Results from the univariate and multivariate tests, carried out on the crania in the Cochabamba population, clearly demonstrate a difference exists between the male and females phenotypes. In males, during the process of body tissue differentiation, major skeletal development enables greater and more functional muscle mass to form than in females. This characteristic, constituting an important property of the biological profile of the population, is characterized by the notable constancy of the sexual dimorphic differences across the cranial dimensions. Incidentally, in only $10 \%$ of the variables was it not possible to show this effect. These facts are consistent with a normal growth and a later development in male individuals in an environment with extensive availability of nutritional resources.

Undoubtedly, the living conditions in prehispanic Cochabamba surpassed that of other localities, where it was found that the proportion of isomorphic variables was higher, ranging between $13 \%$ and $62 \%$ of all measurements. In comparison, values for pre-ceramic populations in northern Chile are $19 \%$ in Morro de Arica and 13\% in agro pastoral group of San Pedro de Atacama.

More extreme values come from the site of Pisagua where the absence of sexual dimorphism is determined from $38 \%$ of the metric variables analyzed. Similarly, in Caleta Huelén 42, $45 \%$ of the variables were unaffected. In late ceramic groups of northwest Argentina, like La Paya, in the Calchaqui Valleys, $27 \%$ of the variables do not manifest sexual dimorphic diffe- 
Table 3.

Cochabamba, statistics for each variable and test the difference between mean values (ANOVA) by sex.

\begin{tabular}{|c|c|c|c|c|c|c|c|c|}
\hline Sex & & Male & & & Female & & & \\
\hline Variable & $\mathrm{N}$ & $\bar{x}$ & se & $\mathrm{N}$ & $\bar{x}$ & se & $\mathrm{F}^{1}$ & $\mathrm{df}$ \\
\hline Maximum Cranial Length & 100 & 175.52 & 0.66 & 133 & 168.64 & 0.64 & $* *$ & 231 \\
\hline Maximum Cranial Breadth & 98 & 137.08 & 0.70 & 133 & 134.56 & 0.53 & $* *$ & 229 \\
\hline Maximum Cranial Height & 93 & 132.49 & 0.55 & 125 & 129.4 & 0.53 & $* *$ & 216 \\
\hline Minimum Frontal Breadth & 98 & 92.02 & 0.46 & 131 & 89.10 & 0.33 & $* *$ & 227 \\
\hline Maximum Frontal Breadth & 96 & 113.92 & 0.57 & 127 & 110.67 & 0.51 & $* *$ & 221 \\
\hline Upper Facial Breadth & 100 & 103.78 & 0.45 & 131 & 99.83 & 0.34 & $* *$ & 229 \\
\hline Upper Facial Height & 87 & 72.33 & 0.64 & 115 & 67.63 & 0.69 & $* *$ & 200 \\
\hline Bizygomatic Breadth & 89 & 137.26 & 0.63 & 117 & 128.39 & 0.56 & $* *$ & 204 \\
\hline External Palatal Length & 65 & 53.2 & 0.33 & 82 & 50.29 & 0.35 & $* *$ & 145 \\
\hline External Palatal Breadth & 58 & 65.31 & 0.40 & 77 & 62.10 & 0.34 & $* *$ & 133 \\
\hline Internal Palatal Length & 64 & 47.55 & 0.37 & 87 & 44.87 & 0.30 & $* *$ & 149 \\
\hline Internal Palatal Breadth & 55 & 42.47 & 0.41 & 78 & 40.42 & 0.28 & $* *$ & 131 \\
\hline Nasal Height & 89 & 51.38 & 0.34 & 117 & 48.68 & 0.29 & $* *$ & 204 \\
\hline Nasal Breadth & 87 & 25.39 & 0.21 & 117 & 25.02 & 0.16 & ns & 202 \\
\hline Orbit Height & 91 & 35.68 & 0.28 & 121 & 35.55 & 0.21 & $\mathrm{~ns}$ & 210 \\
\hline Orbit Breadth & 90 & 37.87 & 0.20 & 122 & 36.85 & 0.15 & $* *$ & 210 \\
\hline Interorbit Breadth & 89 & 23.42 & 0.24 & 127 & 21.94 & 0.20 & $* *$ & 214 \\
\hline Biorbital Breadth & 100 & 95.91 & 0.39 & 128 & 92.41 & 0.33 & $* *$ & 226 \\
\hline Malar Length. Inferior & 81 & 32.91 & 0.33 & 105 & 30.67 & 0.35 & $* *$ & 184 \\
\hline Malar Length. Maximum & 80 & 52.26 & 0.32 & 107 & 48.33 & 0.42 & $* *$ & 185 \\
\hline Cheek Height. Minimum & 91 & 24.35 & 0.29 & 121 & 22.10 & 0.22 & $* *$ & 210 \\
\hline Biauricular Breadth & 97 & 126.57 & 0.56 & 130 & 120.38 & 0.42 & $* *$ & 225 \\
\hline Basion Prosthion Length & 79 & 96.19 & 0.55 & 104 & 91.80 & 0.45 & $* *$ & 181 \\
\hline Cranial Base Length & 92 & 96.85 & 0.37 & 124 & 92.25 & 0.35 & $* *$ & 214 \\
\hline Foramen Magnum Length & 89 & 35.56 & 0.29 & 120 & 34.21 & 0.25 & $* *$ & 207 \\
\hline Foramen Magnum Breadth & 93 & 29.74 & 0.23 & 120 & 28.87 & 0.21 & $* *$ & 211 \\
\hline Biasterion Breadth & 97 & 107.10 & 0.51 & 132 & 103.71 & 0.47 & $* *$ & 227 \\
\hline Mastoid Length & 97 & 29.03 & 0.29 & 128 & 24.32 & 0.28 & $* *$ & 223 \\
\hline Frontal Chord & 97 & 111.24 & 0.57 & 133 & 108.75 & 0.57 & $* *$ & 228 \\
\hline Parietal Chord & 99 & 105.12 & 0.64 & 133 & 102.31 & 0.55 & $* *$ & 230 \\
\hline Occipital Chord & 91 & 100.66 & 0.70 & 120 & 99.13 & 0.69 & $\mathrm{~ns}$ & 209 \\
\hline Age & 100 & 39.30 & 0.81 & 134 & 37.65 & 0.89 & $\mathrm{~ns}$ & 232 \\
\hline
\end{tabular}

Note: F: test sex differences; ${ }^{* *} p<0.01 ; \mathrm{ns}=p>0.05 ; \mathrm{df}$ : denominator degree of freedom. Numerator degrees of freedom equal to 1 .

rences (Cocilovo \& Baffi, 1985). Also in Doncellas (Puna), a cemetery of the Late Period, $26 \%$ of the variables did not differ between sex (Mendonça et al., 1994). Finally, in Trelew, a hunter and gatherer site in Patagonia, $15 \%$ of 41 variables do not exhibit sexual dimorphism (Cocilovo, 1978).

Cochabamba unlike, Pampa Grande (Northwest Argentina), represents a situation in which the differences between males and females reach a minimum expression with $62 \%$ of isomorphic variables from 37 measurements. This fact clearly demonstrates the life conditions based on a subsistence economy with insufficient nutritional resources, which was already seen pre- viously (Baffi \& Cocilovo, 1989; Cocilovo et al., 1994).

The difficulty to establish morphometric differences between both sexes for some variables is certainly caused by problems related to experimental design and the quantity of observations available in each case. Furthermore, assuming an adequate design, the early cessation of growth in a particular region of the skull, like the anatomical units that protect and contain the visual and olfactory systems, can limit the expression of the differences between sexes. For example, this could explain the absence of sexual dimorphism in the dimensions of the orbit and nose in several samples from northern Chile: Morro de 


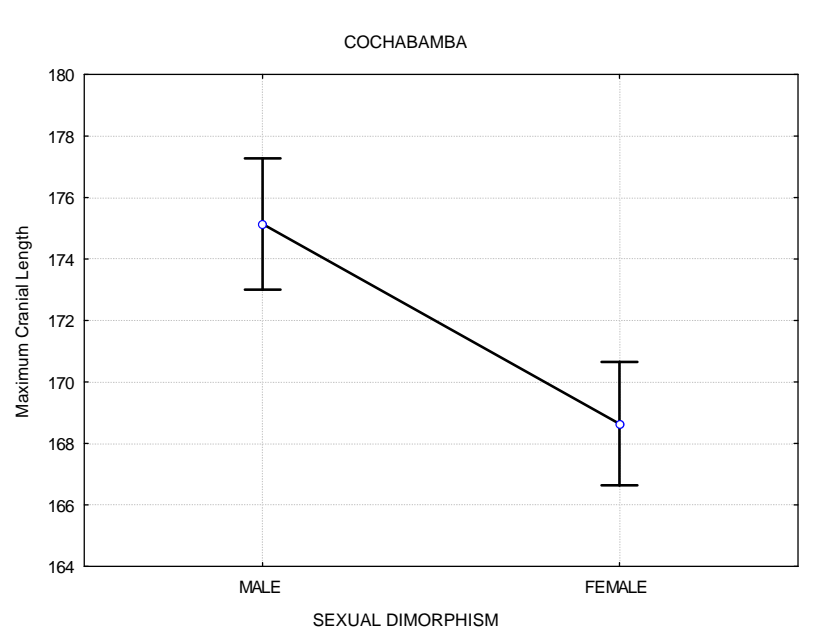

Figure 4.

Sexual dimorphism, Maximum Cranial Length. Vertical bars indicate $95 \%$ confidence interval of the mean distribution.

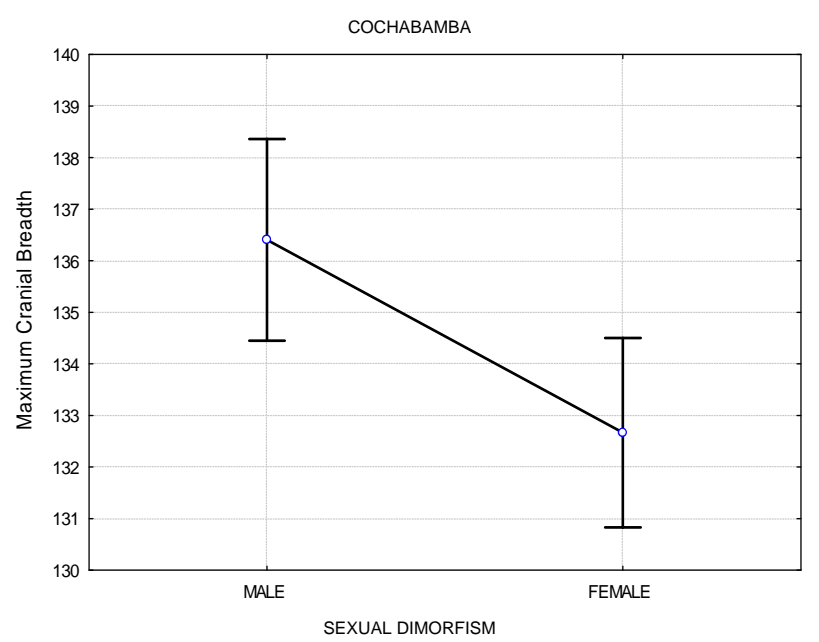

Figure 5.

Sexual dimorphism, Maximum Cranial Breadth. Vertical bars indicate $95 \%$ confidence interval of the mean distribution.

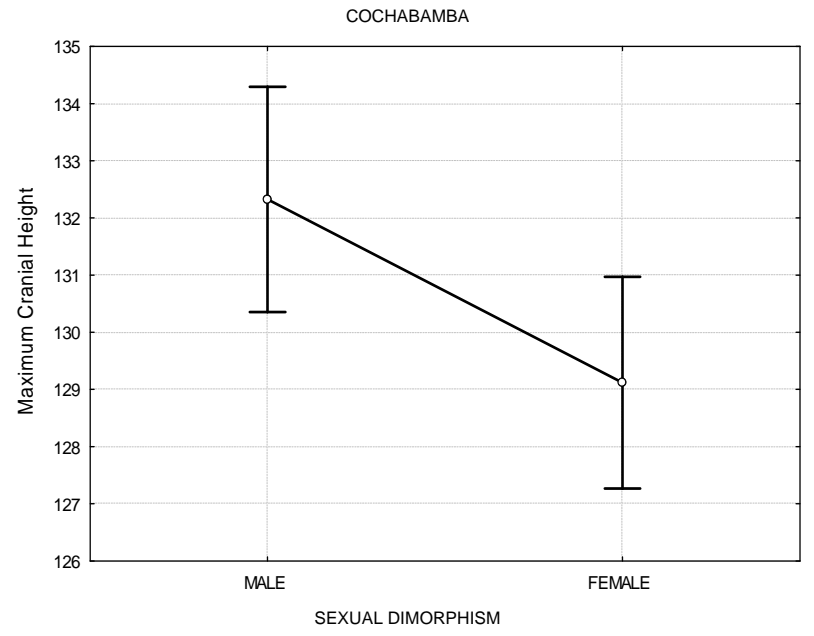

Figure 6.

Sexual dimorphism, Maximum Cranial Height. Vertical bars indicate $95 \%$ confidence interval of the mean distribution.

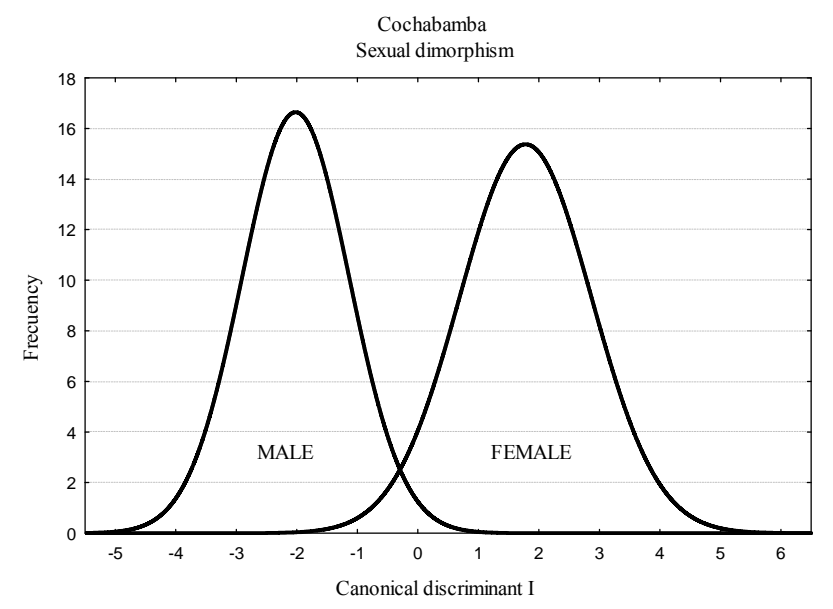

Figure 7.

Discriminant analysis, distribution of individuals of each sex for the canonical discriminant function I.

Table 4.

Cochabamba, reclassification of individuals by sex based on discriminant function.

\begin{tabular}{ccccc}
\hline \multirow{2}{*}{ Sex } & \multicolumn{3}{c}{ Assigned } & Total \\
\cline { 2 - 5 } & $(\%)$ & Male & Female & Observed \\
\hline Male & 100.0 & 37 & 0 & 37 \\
Female & 97.6 & 1 & 41 & 42 \\
Total & 98.7 & 38 & 41 & 79 \\
\hline
\end{tabular}

Arica (Cocilovo et al., 1982), Pisagua (Cocilovo et al., 1999), Caleta Huelén 42 (Cocilovo et al., 2005) and San Pedro of Atacama (Varela et al., 1990b; Cocilovo et al., 1994; Varela et al., 1996); and from northwestern Argentina: La Paya (Baffi \& Cocilovo, 1985), Puna (Mendonça et al., 1994) and Las Pirguas (Baffi et al., 1996).

In summary, the study of sexual dimorphism in ancient populations allows us to make inferences about the expression of a genetic trait that is determined and conditioned by environmental, economic and socio-cultural factors. The obtained information constitutes a window into the past through which we can observe important aspects of life history and the adaptive process experienced by individuals. This process is still occurring uninterrupted, even today, offering a connection between ancient groups and the current populations who inhabit the vast regions of South America. Besides works of this type, others in the future will be able to integrate global databases, similar to the living populations studied by Gustafsson and Lindernfors $(2004,2009)$ to explain the biological variation from a biogeographical point of view or to carry out analysis of the evolution of sexual dimorphism across time (Gustafsson et al., 2007).

\section{Acknowledgements}

The authors would like to thank, not only the editors and reviewers of this manuscript, but also the following for their assistance, support and encouragement on this research and the diverse aspects of the job in general: Deborah Blom, Ingrid Carlstein, William Isbell, and John Janusek. We greatly appre- 
ciate the access to the skeletal collections granted by David Pereira and Ramon Sanzetenea (Museo Arqueológico del Universidad Mayor de San Simon, Cochabamba, Bolivia) and Edmundo Salinas (Museo Arqueológico de la Universidad de Chuquisaca, Sucre, Bolivia).

\section{REFERENCES}

Acsádi, G., \& Nemeskéri, J. (1970). History of human life span and mortality. Budapest: Akadémiai Kiadó.

Bass, W. M. (1987). Human osteology: A laboratory and field manual of the human skeleton. Springfield: University of Missouri.

Buikstra, J. E., \& Ubelaker, D. H. (1994). Standards for data collection from human skeletal remains. Fayetteville: Arkansas Archaeological Survey.

Baffi, E. I., \& Cocilovo, J. A. (1989). Evaluación del impacto ambiental en una población prehistórica: El caso de Las Pirguas (Salta, Argentina). Revista Argentina de Antropologia Biologica, 4, 39-43.

Baffi, E. I., Torres, M. F., \& Cocilovo, J. A. (1996). La población prehispánica de Las Pirguas (Salta, Argentina). Un enfoque integral. Revista Argentina de Antropologia Biologica, 1, 204-218.

Cocilovo, J. A. (1975). Estudio de dos factores que influencian la morfología craneana en una colección andina: El sexo y la deformación artificial. Revista Instituto de Antropología, 2, 197-212.

Cocilovo, J. A. (1978). Estudio de dos factores que influyen en la morfología craneana en una colección patagónica: El sexo y la deformación artificial. Arquivos de Anatomía e Arqueología, 3, 113-141.

Cocilovo, J. A., \& Baffi, E. I. (1985). Contribución al conocimiento de las características biológicas de la población prehistórica de Puerta de La Paya (Salta). Runa, 15, 153-178.

Cocilovo, J. A., \& Marcellino, A. J. (1974). Determinación del sexo en una serie craneana aborigen por medio de las funciones discriminantes. Revista Instituto de Antropología, 5, 17-24.

Cocilovo, J. A., Varela, H. H., \& O'Brien, T. G. (2009). La divergencia genética entre poblaciones del Área Andina Centro Meridional evaluada mediante rasgos no métricos del cráneo. Revista Argentina de Antropologia Biologica, 11, 43-59.

Cocilovo, J. A., Zavattieri, M. V., \& Costa Junqueira, M. A. (1994). Biología del grupo prehistórico de Coyo Oriental (San Pedro de Atacama, Norte de Chile): I Dimorfismo sexual y variación etaria. Estudios Atacameños, 11, 121-134.

Cocilovo, J. A., Varela, H. H., Costa-Junqueira, M. A., \& Quevedo, S. G. (2005). Los pescadores arcaicos de la desembocadura del río Loa (Norte de Chile): El sitio Caleta Huelén 42. Chungara, 37, 5-19.

Cocilovo, J. A., Rothhammer, F., Quevedo, S., \& Llop, E. (1982). Microevolución en poblaciones prehistóricas del área andina. 3. La población del Morro de Arica. Craneometría. Revista de la Universidad Nacional de Río Cuarto, 2, 91-111.

Cocilovo, J. A., Quevedo, S., Varela, H. H., Valdano, S., \& Castro, M. (1999). Biología del grupo prehistórico de Pisagua, costa norte de Chile. Estudios Atacameños, 17, 207-235.

Dembo, A., \& Imbelloni, J. (1938). Deformaciones intencionales del cuerpo humano. Buenos Aires: Humanior.

Dingwall, E. J. (1931). Artificial cranial deformation-A contribution to the study of ethnic mutilation. London: John Bale, Sons \& Danielsson, Ltd.

Dettwyler, K. A. (1992). Nutritional status of adults in rural mali. American Journal of Physical Anthropology, 88, 309-321. doi:10.1002/ajpa.1330880306

Frayer, D. W., \& Wolpoff, M. H. (1985). Sexual dimorphism. Annual Review of Anthropology, 14, 429-473. doi:10.1146/annurev.an.14.100185.002241

Giles, E., \& Elliot, O. (1963). Sex determination by discriminant function analysis of crania. American Journal of Physical Anthropology, 21, 53-68. doi:10.1002/ajpa.1330210108

Guntupalli, A. M., \& Baten, J. (2009). Measuring gender well-being with biological living-standard indicators. In B. Harris, L. Gálvez, \& H. Machado (Eds.), Gender and well-being in Europe: Historical and contemporary perspectives (pp. 43-58). London: Ashgate Ed.
Gustafsson, A., \& Lindenfors, P. (2004). Human size evolution: No evolutionary allometric relationship between male and female stature. Journal of Human Evolution, 47, 253-266. doi:10.1016/i.jhevol.2004.07.004

Gustafsson, A., \& Lindenfors, P. (2009). Latitudinal patterns in human stature and sexual stature dimorphism. Annals of Human Biology, 36, 74-87. doi: 10.1080/03014460802570576

Gustafsson, A., Werdelin, L., Tullberg, B. S., \& Lindenfors, P. (2007). Stature and sexual stature dimorphism in Sweden, from the 10th to the end of the 20th Century. American Journal of Human Biology, 19, 861-870. doi:10.1002/ajhb.20657

Keen, J. A. (1950). A study of the differences between male and female skulls. American Journal of Physical Anthropology, 8, 65-78. doi:10.1002/ajpa.1330080113

Lovejoy, C. O. (1985). Dental wear in the Libben population: Its functional pattern and role in the determination of adult skeletal age and death. American Journal of Physical Anthropology, 68, 47-56. doi:10.1002/ajpa.1330680105

Masset, C. (1989). Age Estimation on the basis of cranial sutures. In M. Y. Iscan (Eds.), Age markers in the human skeleton (pp. 71-103). Springfield: Charles C Thomas.

Meindl, R. S., \& Lovejoy, C. O. (1985). Ectocranial suture closure: A revised method for the determination of skeletal age at death based on the lateral-anterior sutures. American Journal of Physical Anthropology, 68, 57-66. doi:10.1002/ajpa.1330680106

Méndez, M. G., \& Ferrarini, S. O. (2006). Dimorfismo sexual y cefalometría en etnias chaqueñas: Una lectura desde la antropología evolutiva. Revista Española de Antropología Física, 26, 75-92.

Mendonça, O. J., Valdano, S. G., \& Cocilovo, J. A. (1994). Evaluación del Dimorfismo Sexual y de la Deformación Artificial en una muestra craneana del borde oriental de la Puna Jujeña. Revista Argentina de Antropologia Biologica, 2, 25-37.

O'Brien, T. G. (2003). Cranial microvariation in prehistoric south central andean populations: An assessment of morphology in the Cochabamba Collection, Bolivia. Ph.D. Thesis, Binghamton: Binghamton University, State University of New York.

Pinotti, L. V., Rasines, C. H., \& Unsain, R. F. (2005). Tehuelches y mapuches, dimorfismo sexual en condiciones de vulnerabilidad social. Studies in Historical Anthropology, 2, 17-29.

Priotto, J. M. (1990). Diferenciación biológica y dimorfismo sexual entre las poblaciones aborígenes del Chaco Occidental (Chiriguanos, Chorotes, Matacos y Tobas). Degree thesis, Río Cuarto: Universidad Nacional de Río Cuarto.

Pucciarelli, H. M., Carnese, F. R., Pinotti, L. V., Guimarey, L. M., \& Goicoechea, A. S. (1993). Sexual dimorphism in schoolchildrem of the Villa IAPI neighborhood (Quilmes, Buenos Aires, Argentina). American Journal of Physical Anthropology, 92, 165-172. doi:10.1002/aipa.1330920206

Purkait, R., \& Chandra, H. (2002). Sexual dimorphism in femora. Indian Study Forensic Science Communications Research and Technology, 4. URL (last checked 7 November 2012). http://www2.fbi.gov/hq/lab/fsc/backissu/july2002/purkait.htm

Purkait, R., \& Chandra, H. (2004). A study of sexual variation in Indian femur. Forensic Science International, 146, 25-33. doi:10.1016/j.forsciint.2004.04.002

Saunders, S. R. (1992). Subaldult skeletons and growth related studies. In S. R. Saunders, \& A. Katzenberg (Eds.), Skeletal biology of past peoples: Research method (pp. 1-20). New York: Wiley-Liss.

Seber, G. A. F. (1984). Multivariate observations. New York: Wiley. doi: $10.1002 / 9780470316641$

Stini, W. A. (1969). Nutritional stress and growth: Sex difference in adaptive response. American Journal of Physical Anthropology, 31, 417-426. doi:10.1002/ajpa.1330310316

Stinson, S. (1985). Sex differences in environmental sensitivity during growth and development. Yearbook of Physical Anthropology, 28, 123-147. doi:10.1002/ajpa.1330280507

Varela, H. H., Priotto, J. W., \& Cocilovo, J. A. (1990a) Evaluación del dimorfismo sexual en una muestra de nativos de la Puna Jujeña. Revista de la Universidad Nacional de Río Cuarto, 10, 33-42.

Varela, H. H., Cocilovo, J. A., \& Costa Junqueira, M. A. (1990b). El dimorfismo sexual en la población prehistórica de San Pedro de Atacama, Chile. Chungara, 24-25, 159-166. 